\title{
Eroding Fabrics of Communal Land Ownership in Papua New Guinea
}

\author{
Mr. Lepani Karigawa
}

Lecturer, Department of Surveying and Land Studies, Property Studies Section, Papua New Guinea University of Technology

Email: lepani.karigawa@pnguot.ac.pg

\begin{abstract}
This paper analyses the perceptions of 120 landowner-households of Nanadai Clan of Gaire Village in Central Province and Sek Clan of Madang Province concerning breaking apart of communal ownership of customary land in PNG. Previous researches have argued that there is lack of a clear distinction between individual and communal property rights in some parts of Papua New Guinea. The existing weak land administration system and mechanisms have contributed immensely towards tearing apart the bond and connections between clan members and the dismantling of communal land ownership in Papua New Guinea thus, compromising national land administration values and standards. Current practices reveal that customary land is held at the sub-clan, family and individual levels, while the major clans just bear ownership name-tag. The existing land legislation in Papua New Guinea recognises that ownership of customary land is vested in the clans, however, the realities on the ground from the findings of this research indicate otherwise. Therefore, this papercalls for the strengthening of the weak land administration functions and mechanisms together with the review of all existing laws to improve the standards of land administration system in the country. This paper argues that communal land ownership in Papua New Guinea is slowly breaking apart causing disharmony between
\end{abstract}

Keywords- Communal ownership, Clans, Land Administration System and Land Administration Standards.

\section{NATURE OF CUSTOMARY LAND PROBLEM IN PNG}

Man and land in Papua New Guinea are inseparable and the association between the two is at the heart of the economic, cultural and spiritual foundations of society, which invariably underpins the individual's and group's sense of social identity and belonging (Koczberski, Numbasa, Germis and Curry, 2017; Sillitoe, 1999). This link to social and cultural identity also underpins the common view among landowners that land is inalienable. Even customary land that has been acquired by the state or converted to freehold title is rarely seen as being alienated permanently from customary ownership (Chand and Yala, 2006; Filer and Lowe, 2011; Curry et al., 2012). Customary land tenure arrangements vary across the country, but generally, under customary tenure, rights to land are based on a mixture of descent, residence and participation in communal activities (Cooter, 1991; Larmour, 1991; Curry, 1997; Koczberski et al., 2017 \& 2009). Exclusive individual landownership and inheritance are generally limited in PNG.

ILG incorporation is already being seeing as the major problem because what the major clan holds is just the skeleton or structural frame of ownership but the control and use of the customary land is fully vested in individuals and family units in some communities in PNG (Karigawa 2016). Traditionally, land ownership through communal arrangements keeps the clans/tribes in Papua New Guinea intact but in the modern economy; it becomes an obstacle to economic and other forms of development on customary land (Karigawa, Babarinde and Holis, 2016; Curry et al., 2012).

Lakau (1991) and Armitage (2002) have argued that legislations in PNG dealing with land directly or indirectly are too many and most of these laws are not compatible to one another creating more problems for the already weak land administration system in PNG. This argument is supported by Martin (2005); Grant, Ting and Williams on (1999) whilst Green Peace Australia Pacific (2012) stated that land grabbing issues in PNG is a result of the weak land administration system.

The purpose of this study is to investigate the causes of communal land ownership break-down and suggest way forward to mitigate these challenges and thereby prevent further disintegration of customary land tenure in PNG. The paper consists of six sections. After the introduction and problem statement in the first section, Section 2 presents an overview of communal land ownership in PNG, followed 
by an outline of the hypothesis and research questions in Section 3. The research method and findings are presented in Sections 4 and 5 respectively, while the concluding section (Section 6) summarizes the paper and offers some advice in terms of policy implications of the findings.

\section{AN OVERVIEW OF COMMUNAL LAND OWNERSHIP IN PNG}

The complexity of the manner in which customary land is owned in PNG cannot be denied. Communal land ownership is recognised by the existing land legislation, which denies individual ownership - a bond that has created a strong relationship between man and his land over the years. Champagne (2017) has observed that distribution of land resources has worked for many indigenous nations for thousands of years. The tribal entities managed the land collectively. However, there are rules that uphold the rights of tribal sub-groups for access to land sufficient for their livelihood. The land is held not only for gathering food and resources, but tribal members have an obligation to maintain the land in good use for future generations.

Since the families, clans or villagers that use land expect to live in the same area for many future generations, the tribal members have a vested interest in maintaining the ecological and cultural soundness of their allocations. However, during the course of maintaining the land for future generations by individuals, their fathers transfer ownership from the main clan to individuals and families. This is the birth of a mixed communal ownership in PNG. Cousins (2009) in reviewing the work of Bruce (1986) regarding communal ownership in African nations stated that "communal tenure systems are in fact mixed tenure regimes, comprising variable bundles of individual, family, sub-group and larger group rights and duties in relation to a variety of natural resources". Therefore, communal ownership of land began to shift towards ownership, control, use and disposition by specific groups within the main community, together with land obligations that are vested in those specific groups (subclans) and individuals.

Curry et al. (2012) strongly argued that the "adaptations and modifications to customary land tenure by landowners in response to these key drivers offer lessons to inform land reform policies". They further stated that "whilst customary land tenure is recognised in PNG's Constitution, it has largely been considered problematic in discussions of land reform." Land reform in PNG and elsewhere in the Pacific has been dominated by the assertion that customary tenure is incapable of providing secure property rights necessary for facilitating investment and the commercial use of land. Thus, attempts at land reform in PNG have been based on the notion that secure individual property rights through land titling and tenure conversion are a prerequisite for building a favourable investment climate and fostering economic development.

The analysis from the African countries and other indigenous countries around the globe reveals that there is significant shift from communal ownership to individual ownership. Elahi (2013) argues that PNG should shift from communal to privatised ownership to make land accessible for agricultural development and this has been supported by some other studies (e.g. Karigawa, Babarinde and Holis, 2016; Curry et al., 2012), which claim that communal ownership is an obstacle to economic development in PNG. Thus, there are already clear indications that PNGis slowly moving towards private ownership of customary land although it is not legally recognised yet.

Although there are already laws in place protecting customary land from being sold and leased, there are continuous sales of customary land across PNG. In most cases, land sales tend to be through informal verbal agreements between the transacting parties, with an individual's access and use rights to the land loosely defined (Curry et al., 2012). Members of the broader landowner groups are sometimes not aware that land has been 'sold' to an 'outsider' but this can sooner or later become a major source of discontent within the major landowner group. Disputes over 'purchased' customary land (and even over land initially gifted to migrants) have been increasing over the past 10 years. These disputes arise not so much because migrants and landowners have different understandings of land use rights - e.g. the right to plant oil palm - but rather because they have different perceptions of land 'ownership', which means that their respective interpretations of the obligations and expectations associated with land transactions can be very different (Curry et al., 2012).

Therefore, a significant challenge for policy makers in PNG will be how to deal with the proliferation of informal (and sometimes illegal) land transfers taking place, as landowners develop their own arrangements for land mobilisation outside government structures, and as they seek to capitalise on the demand for urban and rural land by land-poor migrants". How policy makers can develop an effective reform program and land administration system to accommodate the range of informal and semiformal arrangements already well established will be one of the principal challenges for land reform in PNG. Customary land in PNG has gone through a lot of land 
reforms in the past to present. Past land reforms were geared towards security of tenure while current land reforms are more about transforming customary land into a saleable commodity that can be transacted in the open market (Curry et al., 2012).

\section{HYPOTHESIS AND RESEARCH QUESTIONS}

Having regard to the above situation analysis, this paper attempts to test one hypothesis and answer four research questions. The hypothesis states that: Communal land ownership is slowly breaking apart in PNG communities. The four research questions are as follows:

i) What are the main causes of communal land ownership break-down in PNG?

ii) What are the flaws in the land administration system in PNG? iii)

iv)
What are the views of customary landowners regarding the protection by existing land laws and the customary land title?; and What is the way forward for customary land ownership in PNG?

\section{METHOD}

The paper uses a stratified random sample to gather the perceptions of respondents selected from two sub-clans in PNG. A stratified random sample is a sampling method that requires the population to be divided into smaller groups called strata from which random samples are taken.

This research is based on two sub-clans of Laurina Clan of Gaire Village in Central Province and Sek Clan of Sek Island in Madang Province. A representative sample size of 120 landowners, representing $67 \%$ of the total population of 360 landowners was interviewed. Table 1 illustrates the sampling frame and sample size.

Table.1: Sample Population

\begin{tabular}{|c|c|c|c|c|c|c|c|}
\hline \multicolumn{9}{|c|}{ Stratified Random Sample Selection } & Sample \\
$\begin{array}{c}\text { Major Clan } \\
\text { Name }\end{array}$ & Sub-clan & $\begin{array}{c}\text { Total } \\
\text { population } \\
\text { (main clans) }\end{array}$ & $\begin{array}{c}\text { Total } \\
\text { Population } \\
\text { (sub-clan) }\end{array}$ & $\begin{array}{c}\text { Target } \\
\text { Total Number } \\
\text { Returned }\end{array}$ & $\begin{array}{c}\text { Total Returned } \\
(\%)\end{array}$ \\
\hline Laurina & Nanadai & 500 & 160 & 50 & 80 & 64 & 80 \\
\hline Sek Clan & Panuwadan & 700 & 200 & 50 & 100 & 56 & 56 \\
\hline \multicolumn{2}{|c|}{ Total } & 1,200 & 360 & 100 & 180 & 120 & 67 \\
\hline
\end{tabular}

Source: Author, 2018

Primary data was obtained through questionnaires, interviews and site observations, while secondary data was sourced from relevant literature and public records. Data was analysed using SPSS, excel and statistics, particularly Chi-square Test $\left(\chi^{\mathbf{2}}\right)$. At this juncture, it is worthy of note to add that the research leading to this paper faced two main limitations. First, funding constraints made it impossible for the author to investigate more clans in other parts of PNG. Second, the researcher was unable to investigate a matrilineal system, thus both sample populations are from the patrilineal system in PNG.

\section{FINDINGS AND DISCUSSIONS}

In this section, an attempt is made to test the hypothesis and answer the four research questions posited in Section 3 of the paper.

i) Test of Hypothesis
$\mathrm{H}_{\mathrm{o}}$ : Communal land ownership is not slowly breaking apart in PNG communities.

$\mathrm{H}_{1}$ : Communal land ownership is slowly breaking apart in PNG communities.

This above hypothesis $\left(\mathrm{H}_{1}\right)$ can be tested using current indications of customary land ownership in PNG. The protection over customary land by existing laws gives full recognition to the clans and tribes to own and control customary land while individuals, families and smaller groups have user rights over the land. Any land dealings on customary land are done through their ILGs. Findings of the research indicate that major clans and the sub-clans have very little control over the land. Currently ownership of the land vests in families and individuals. Figure 1 shows the responses of landowner households regarding ownership of land at the current time in PNG. 


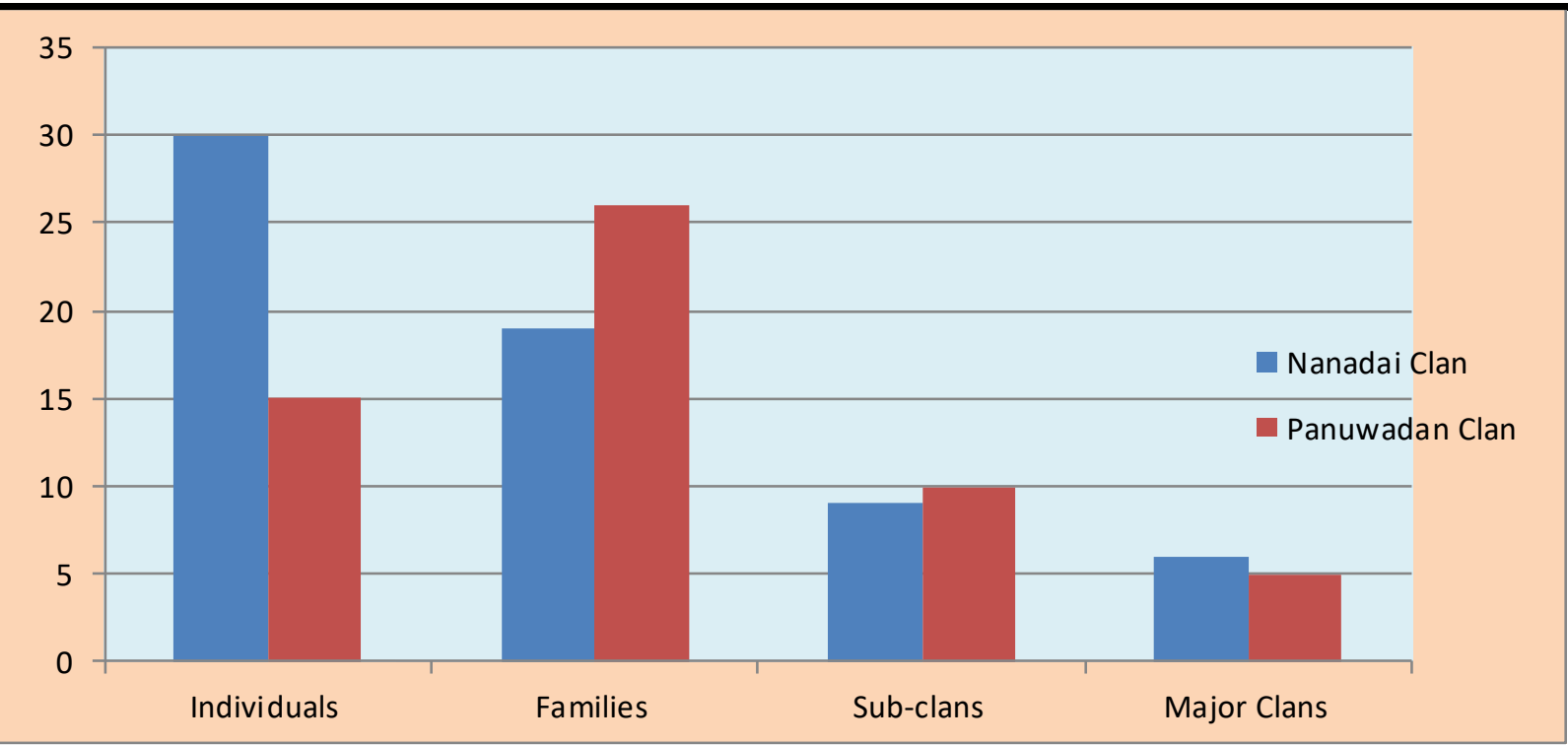

Fig.1: Various levels of customary land ownership

Source: Author, 2018

On the hand, the results from the landowners regarding the flaws in the land administration system are presented in Figure 2.

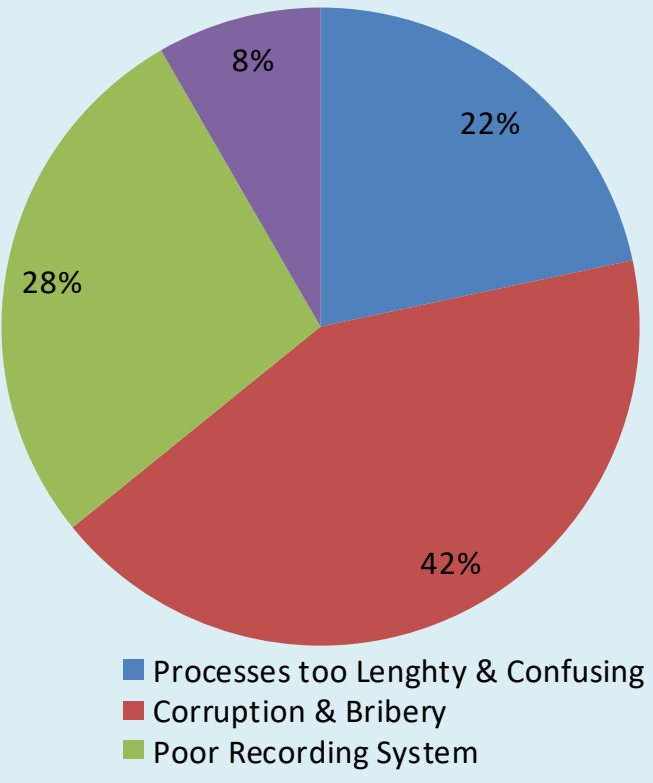

Fig.2: Land Administration flaws in $P N G$

Source: Author, 2018

The results from the perception of landowners regarding the land administration system in PNG already reveal that there is high level of corruption and bribery in the system thus destroying the land administration system in the country. This is followed by poor recording system, lengthy processes and confusing to the land owners and old systems still in use. This paper argues these factors have contributed immensely towards tearing apart of the customary land tenure system in the country.

Moreover, current indications reveal that many members of the major clans do not have the right to use land that is owned by the other member of the clan. Its use must come with consent from the one who claims to be the owner. Land disputes are becoming common between members of 
the same clan. The respondents argued that land is more secured and easily accessed when it is individualised than when it owned by the community under the ILGs. The proponents of strong individual rights have suggested that a registered individual title, backed by effective land administrative systems, provides the greatest certainty and security. For example, Carson (2009) pointed out the same argument regarding communal ownership in Africa claiming that "there are ambiguities in the legal systemand institutional configurations that were inherited during the colonial era and reproduced after independence." The results have indicated that communal land ownership in PNG is no longer intact and it is gradually breaking apart. About $54 \%$ and $70 \%$ of the respondents from Panuwadan and Nanadai clans respectively claimed that PNG customary land interests and rights have been inherited by families and individuals. Therefore, based on these findings, our hypothesis is supported by available data. ii) Research Question 1: What are the main causes of communal land ownership breakdown in PNG?

The research has identified five main causes (Figure 2) of communal land ownership break-down in PNG. The two very significant results are: (a) Benefits are not equally distributed, which accounts for $46 \%$ of reasons given by the respondents and (b) Increase in population $(27 \%$ of responses obtained). These two are followed by land disputes within the clan (13\%), shortage of land or land not easily accessed (4\%). It is contended that the weak land administration system and incompatibility of land laws (Lakau 1991), together with other land-related issues have caused this break-down in the tenure system. Thus, there will be problems of incorporating ILGs under big clans, particularly when it comes to property listings of the ILG.

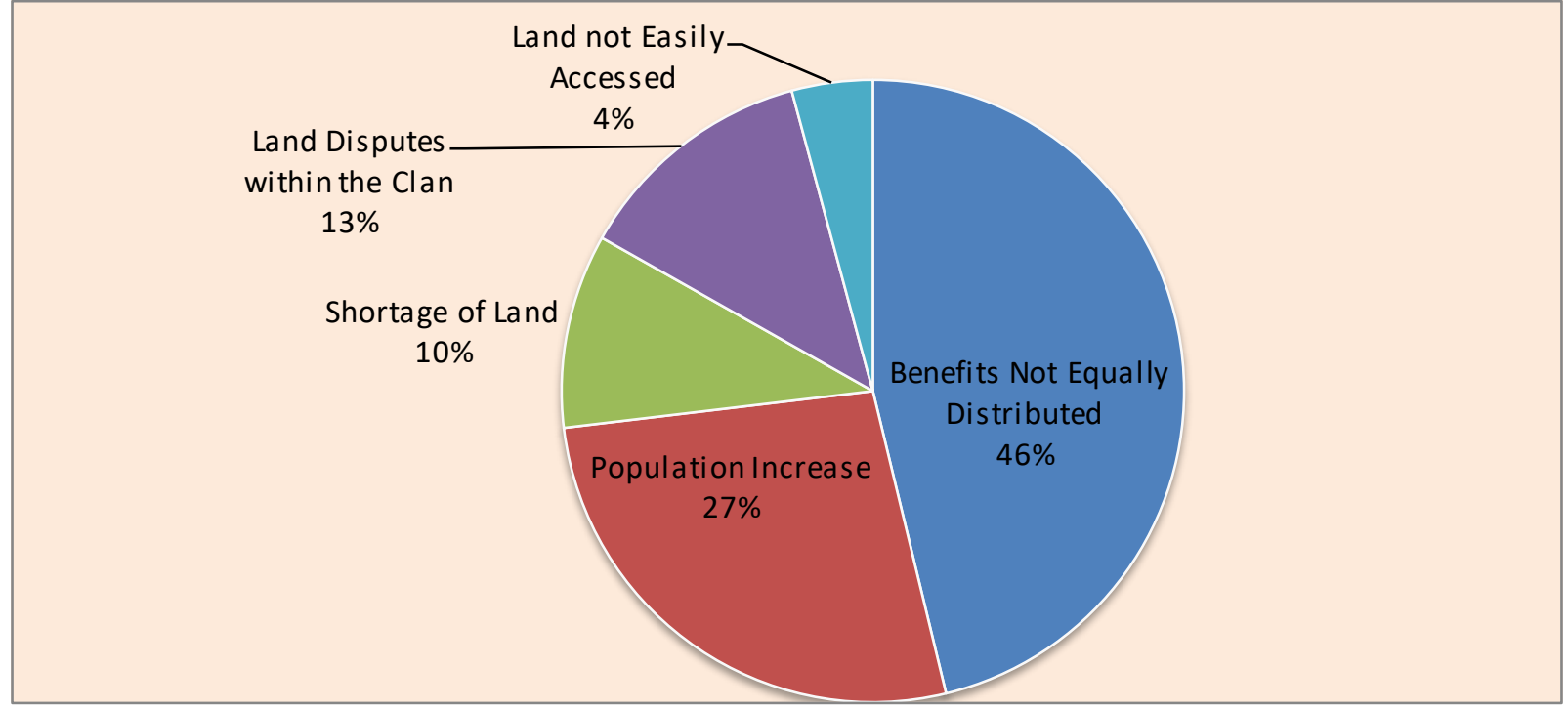

Fig.3: Causes of Communal Ownership Break-down in PNG

Source: Author, 2018

The most likely scenario is that ILGs will have to negotiate with the individuals and families for release of the land to be listed under its property listing. However, our past experience reveals that individuals claiming ownership over customary land that was held and controlled by major clans in the past have been claiming bigger cuts from the proceeds of the land than any other ordinary land owners.

iii)

Research Question 2: What are the flaws in the land administration system in PNG?

Land administration systems (LAS) are about addressing land problems by providing basic infrastructures for implementing land-related policies and land management strategies to ensure social equity, economic growth and environmental protection. Moreover, land administration is the manner in which the rules of land tenure are applied and made operational. The land administration system in PNG has faced a lot of challenges in the past to present date and appears to be weak as claimed by Armitage (2002), Goldman (2005) and Lakau (1991). This paper supports the findings of previous studies in this regard as indicated in Figure 3. 


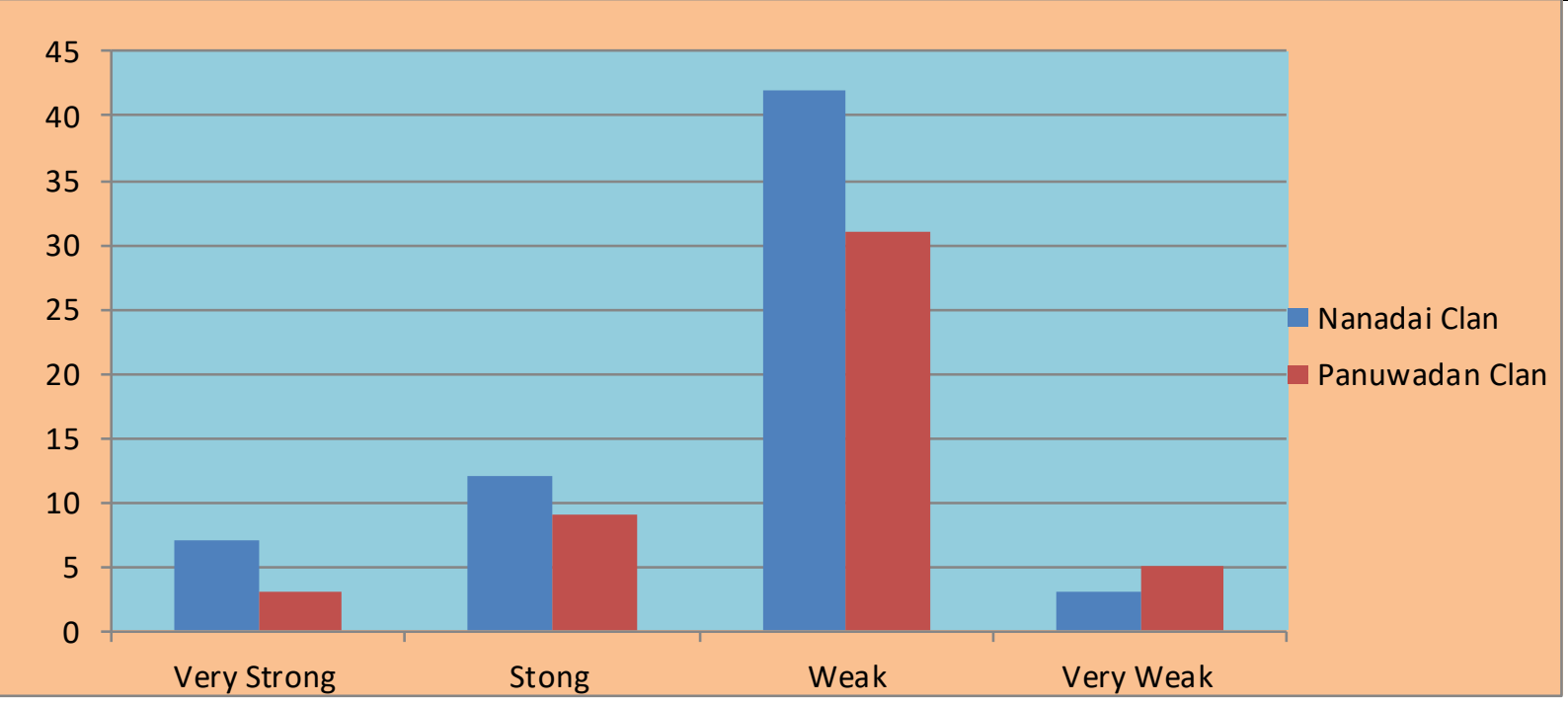

Fig.4: Land Administration System (LAS) in PNG

Source: Author, 2018

This research supports the findings of Grant, Ting and Williams on (1999), when they stated that "the humankindland relationship is dynamic and change is occurring at a pace faster than at any other time in history". Global economic, social and technological factors, the need for sustainable development of land, and macro-economic as well as micro-economic reforms are having a substantial impact on land administration systems. Most land administration systems today are not adequate enough to cope with the increasingly complex range of rights, restrictions and responsibilities in relation to land, which are influenced by such factors as water, indigenous land use, noise and pollution together with other land-related activities. In short, land information and land administration systems need to be re-engineered and allowed to evolve to face the increasing complexity of the humankind-land relationship. For PNG to meet world standards in terms of valuation and land administration system, it has to address the flaws in the land administration system. This paper argues that the break-down of the tenure system is the result of the weak land administration system that PNG has experienced over the past many years. The variables used in the Chi-square Test are as follows: Land administration system, land laws, land disputes and security of tenure thus yielding a Chi-square Value of $\left(\chi^{2}\right)$ of 2.01 and $P$ Value of 0.61 or $61 \%$. Thus, the weak but positive correlation shown in Table 2 and the Chi-Square Test Value of 2.01 and $\mathrm{P}$ Value of 0.61 together with the results in Figure 3 calls for re-engineering of the land adminis tration system to meet the increasing and complex nature of customary land tenure in PNG to avoid the total break-down of the customary land tenure system.

Table.2: Correlation Analysis of Tenure Breakdown and Land Administration System in PNG

\begin{tabular}{|l|l|l|l|l|}
\hline \multirow{2}{*}{ Variables } & \multicolumn{4}{|c|}{ Pearson Correlation (r) } \\
\cline { 2 - 6 } & Nanadai Clan & \multicolumn{2}{l|}{ Panuwadan Clan } \\
\hline Variable 1 & 1 & $0.379^{* *}$ & 1 & $0.377^{* *}$ \\
\cline { 2 - 6 } & & 0.000 & & 0.000 \\
\cline { 2 - 6 } & 64 & 64 & 56 & 56 \\
\hline Variable 2 & $0.379^{* *}$ & 1 & $0.377^{* *}$ & 1 \\
\cline { 2 - 6 } & 0.000 & & 0.000 & 56 \\
\cline { 2 - 5 }
\end{tabular}

**. Correlation is significant at the 0.01 level (2-tailed) for both sample groups

Source: Author, 2018 
The Pears on Correlation (r) of 0.38 indicates that there is a positive but weak correlation between communal ownership and the land administration system, has $61 \%$ chances of breaking down in PNG societies if the land administration system is not overhauled and existing land laws are not reviewed to meet the current ownership status quo and development aspirations of landowners in Papua New Guinea.

By re-engineering the land administration paradigm, it should address is sues such as multiple titles, ILG fissioning, land dispute resolutions, land grabbing, fraudulent land registration, and other land administration is sues.

i) Research Question 3: What are the views of customary landowners regarding the protection by existing land laws and the customary land title?

The existing land laws together with the Constitution of the Independent State of PNG give full protection over customary land. Therefore, it can be concluded that there is full tenure security. However, even though the laws are very clear on the sale, lease and other dealings on customary land, landowners are still defying the protection given by law and continuously sell customary land to foreigners. The findings of this research in Figure 3 reveal that landowners are dissatisfied that land laws are not protecting the rights of the landowners and there is already a sense of insecurity among the landowners over their customary land. However, it is hoped that the recent amendments of the ILG Act, the Land Registration Act and the Land Act currently under review will bring new hopes to the landowners.

Moreover, the results reveal that about $23 \%$ of the landowners (Figure 4) claim that the customary land title that is currently issued to the ILGs is not clearly defined by law. The title is claimed to be a freehold interest but the characteristics of the customary land title does not fit into any of the freehold interest categories. Therefore, it is very confusing to say that it is a freehold interest. Moreover, the ILG Act states that upon registration, all customs cease to operate for the duration of the title but on the other hand, the nature of the land remains customary land, thus this paper argues that there are still some elements of custom embedded in it.

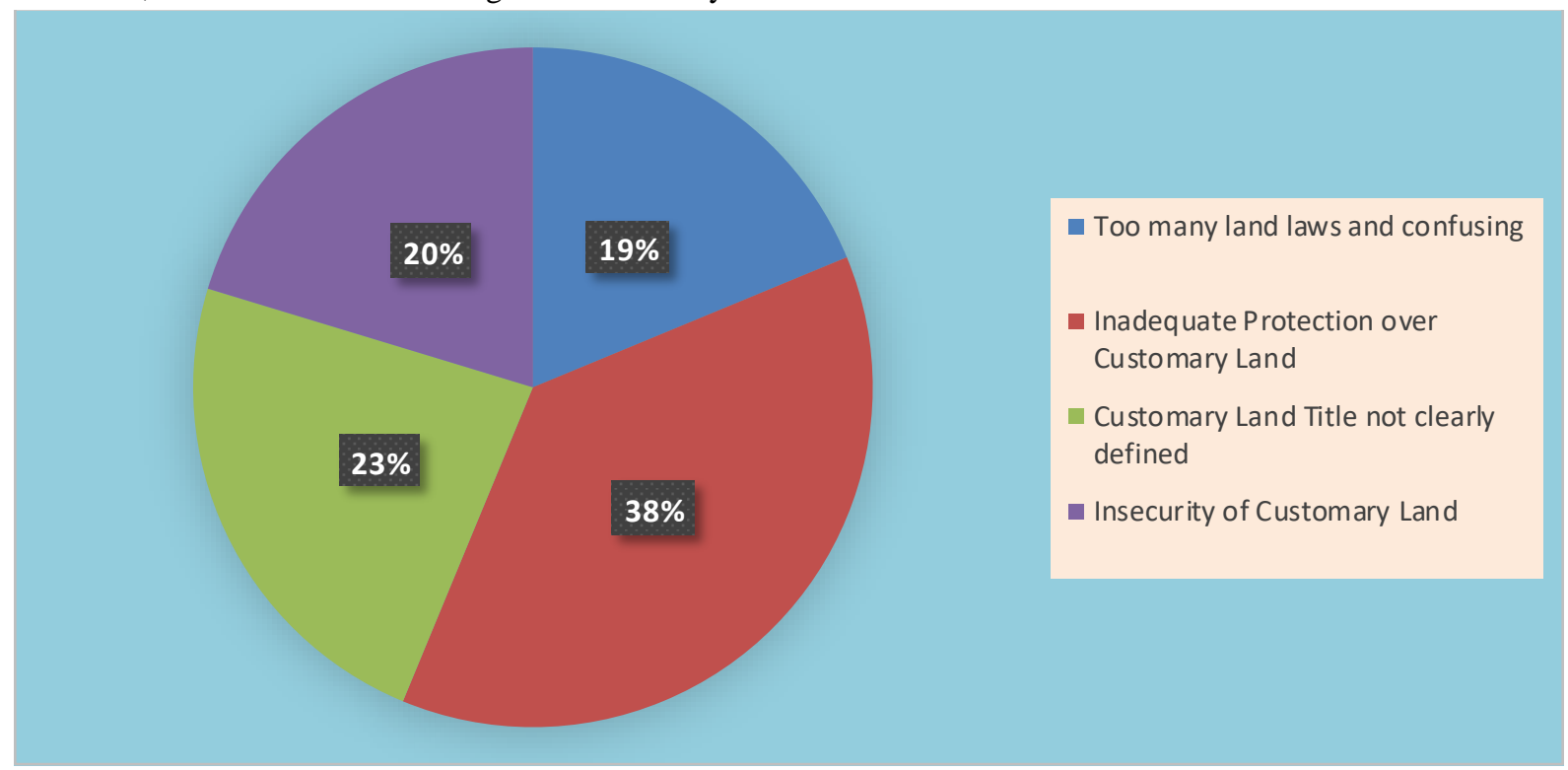

Fig.4: Views of Landowners regarding PNG's Existing Land Laws

Source: Author, 2018

Therefore, it can be concluded that by default, the law calls the title a freehold interest but in reality, it is not a freehold interest. This paper argues that the best category that this title can fall under is the sui generis group of properties because the customary land title is very unique and special. Sui generis groups or classes of properties are unique and special classes of properties that are set aside from the rest of the properties. Thus, the customary land title in PNGbest fits categorization into the sui generis class of properties.

\section{CONCLUSION AND POLICY IMPLICATIONS}

The purpose of this paper is to analyse the perceptions of landowners in regard to communal land ownership break- 
down in PNG and suggest ways to resolve the issues. Two customary landowner groups were investigated through stratified random sampling of two sub-clans namely Nanadai Clan of Gaire Village of Central Province and Panuwadan Clan of Sek Island in Madang Province. Both sub-clans are from the patrilineal societies and appear to be from the coastal regions of Papua New Guinea. Due to varying customs across all communities in PNG, the views of the landowners vary according to the way they interact with their land. This paper argues that communal landownership in PNG is slowly breaking apart.

There is a positive but weak correlation (38\%) between communal land ownership break-down and land administration system indicating that the land administration system in PNG is weak for purposes of managing the affairs of customary land tenure in these challenging times. Furthermore, there is a negative perception by the landowners regarding the land laws in PNG suggesting that current land laws are not protecting the landowners' rights fully thus huge tracks of customary land were taken away from the landowners Green Peace Australia (2012). The findings supported the argument by Champagne (2017) stating that Indigenous nations are confronted with small and often shrinking land bases that do not provide the necessities of food and resources for growing populations. Privatisation of land takes land and resources out of collective tribal management. It is difficult to reclaim privatised land allotments once tribal members are granted them, usually by government policies. Thus, the concept of land ownership in PNG is particularly problematic, as is the idea that before "ownership" all things were held in common with everybody having equal rights to the same thing, or belonged to nobody as claimed by Du Plessis \& Frantz (2013). Du Plessis \& Frantz (2013) in reviewing the work of Bennett (2004) highlighted that "it is more likely that, before the concept of individual ownership emerged, only rights of use were protected". With the introduction of commerce, an exchange value had to be attached to a commodity, and in this context ownership provided the answer in securing the property. With ownership came the idea of "absoluteness" that implied that one person could hold all the entitlements in a certain property, and dispose of it at free will. This differs remarkably from the pre-colonial era where different interests in the same property could vest in different holders, and where these interests are furthermore flexible and ever changing. Therefore, this paper argues that the findings from the literature together with the findings of this research assert that communal ownership in PNG is slowly breaking apart.

The findings of this paper are important for policy formulation and implementation and review of the existing land laws in Papua New Guinea for good and secured tenureship particularly on customary land. The complexity of the customs cannot be denied and customary landownership in PNG evolved around these complex customs.

Thus, to answer the last research question, this paper recommends key strategies that could be adopted to mitigate the challenges facing customary land tenure as follows:

\section{- Re-engineering the Land Administration System}

Land administration is the foundation of tenureship in any country, thus it forms the basis for valuation, land administration mechanisms and property management. The land administration system in PNG is an adopted system from the colonial era. Thus it is believed that land problems had been inherited all along. Many of the concepts used are foreign concepts that PNG needs to revise to suit the needs of our tenure system and land development aspirations of the landowners in the country. Re-engineering the Land Administration System should mitigate issues such as:

a) Double titling;

b) Land grabbing;

c) ILG fissioning;

d) Security of Tenure;

e) Flexibility for collateral purposes and

f) Many other land administration related issues

The above issues are believed to be some of the contributing factors towards the break-down of communal ownership in PNG

\section{- Review of all land laws}

The results from this research have indicated that laws are not protecting the rights of the land owners and there is already a sense of insecurity regarding the laws. Moreover, the Land Act 1996 states clearly that customary land should not be sold to any other persons except to the State. However, there is evidence of increasing customary land sales. Thus there is a great deal of need to toughen the existing laws to protect landowners from losing their land. Moreover, these laws must be compatible to each other to avoid confusion among the landowners. The titles given to landowners must be given the full strength like any other titles. 
- Institutional Involvement - A wake up call to PNGIVLA

The Papua New Guinea Institute of Land Administrators and Valuers (PNGIVLA) must take a leading role and be active in the formulation of the Land Policies and review of Land legislation and any other land-related dealings in PNG. The experts in Valuation, Land Administration and Property Management in PNG are the members of the Institute. The Institute must be vocal in all bad land dealings and must put forward proper mechanisms to mitigate the issues of land administration, valuation and property management before calling for adopting world standards. The Institute must be neutral to fight for justice for the landowners. It must be at the forefront to stand side-by-side with the Department of Lands and Physical Planning fighting against the giants of land grabbing to reclaim land for the land owners that were lost in the past and continue to fight to protect the land rights and resources of the indigenous people of PNG. Moreover, the paper argues that PNGIVLA should be active in recommending its members for Valuer Registration because the strength of the institute lies with its registered valuers and financial members.

It is the view of this paper that PNGIVLA will compromise the world standard in valuation, land administration and property management disciplines if its backyard contains a backlog of unresolved issues or is not actively involved in decision-making regarding efficient land dealings in PNG.

\section{- Codification of PNG Norms and Customs with respect to Communal Ownership}

This concept is adopted from Karigawa, Babarinde and Holis (2016) and Du Plessis \& Frantz (2013). This paper understands that with the advent of constitutionalism in Papua New Guinea, customary laws (made of traditional norms and customs) will of necessity be elevated alongside Statutory provisions (such as Acts of Parliament) and Common Law being recognised and accepted as one of the sources of law in the country. However, these norms and customs appear to be very complex in nature. Dealing with these norms and customs is not an easy task for land administrators and valuers when it comes to customary land dealings. Therefore, this paper argues that the on-going codification of customs in PNG, like that of South Africa and other some other African countries be pursued to a logical conclusion to cover all the 22 provinces in PNG. The codification of traditional norms, values and customs will create flexibility needed in dealing with customary land in PNG.

\section{ACKNOWLEDGEMENT}

I take this time to thank Professor Babarinde, Associate Profess or Dr. Sailesh Samanta and Dr. Roney Dotauna and my colleagues in the Department of Surveying and Land Studies at Unitech for the technical assistance offered during the preparation of this paper. I am greatly indebted to Professor Babarinde who is always around me and teaching me new skills and techniques in research.

\section{REFERENCES}

[1] Armitage, L. (2002), Customary Land Tenure in Papua New Guinea: Customs and Commerce at the Interface, A Case Study of Ahi Peoples' Land, Lae, Morobe Province, Queensland University of Technology, Brisbane; Available at:

[2] http://www.prres.net/Papers/Armitage_indigenous_pro perty rights_custom \& commerce_PNG.pdf, accessed on 15 June 2014.

[3] Armitage, L. (2000), Indigenous property rights: Custom \& Commerce at the Interface, Brisbane: Queensland University of Technology; Available at: http://scholar.google.com/s cholar?biw $=320 \& \mathrm{~h}=303 \& \mathrm{u}$ $\underline{m=1 i e}=U T F 81$ \& cites 93615458325954, accessed on 20 August, 2015.

[4] Attributes of Good Governance, Available at: http://www.wri.org/blog/2015/02/qa-mark-robinsonrole-good-governance-sustainable-development, accessed on 13 December, 2016.

[5] Australian Aid, 2008; Available at: http://www.ausaid.gov.au/publications/pdf/MLW Vol umeOne Bookmarked.pdf, accessed on 13 December, 2017).

[6] Bennett TW Customary law in South Africa (Juta, Cape Town 2004).

[7] Bendor, J. and Swistak, P. (2001), The Evolution of Norms, American Journal of Sociology, Volume 106, Number 6,pp. 1493-1545.

[8] Brundtland Commission (1987), Report of the World Commission on Environment and Development, United Nations.

[9] Burton, J. (1991), 'Social Mapping,' in P. Larmour (Ed.), Customary Land Tenure: Registration and Decentralisation in Papua New Guinea. Port Moresby: Australian National University, New Guinea Research Unit (Bulletin 40).

[10] Champagne D (2017) Is Keeping Communal Land Possible? For indigenous land is essential

[11] Chand, S., Ondopa, J. and Nao, L. (2014), Use of land lease as collateral for accessing formal sector finance 
in Papua New Guinea (National Research Institute Issues Paper No. 7), Port Moresby: National Research Institute.

[12] Commission of Inquiry into the Special Agriculture and Business Leases, Available at: http://www.coi.gov.pg/sabl.html, accessed on 24 January, 2017.

[13] Claassens, Aninka, 2005, 'The Communal Land Rights Act and women: Does the Act remedy or entrench discrimination and the distortion of the customary?'. Occasional Paper 28, Cape Town: Programme for Land and Agrarian Studies, University of the Western Cape.

[14] Cooter, R. D. (1989), Issues in Customary Land Law, Port Moresby: Institute of National Affairs (Discussion Paper 39).

[15] Cousins, Ben and Aninka Claassens, 2004. 'Communal land rights, democracy and traditional leaders in post-apartheid South Africa'. In Securing Land and Resource Rights in Africa: Pan-African Perspectives, ed. M. Saruchera, 139-54. Cape Town: Programme for Land and Agrarian Studies, University of the Western Cape.

[16] Cousins, Ben, 2008. "Characterising 'communal' tenure: nested systems and flexible boundaries", in: Aninka Claassens and BenCousins (eds). Land, Power and Custom: Controversies generated by South Africa's CommunalLand Rights Act. Cape Town: UCT Press and Athens: Ohio University Press (109-137).

[17] Cousins, Ben, 2008. "Contextualizing controversies: communal tenure reform in post-apartheid South Africa", in: Aninka Claassens and Ben Cousins (eds). Land, Power and Custom: Controversies generated by South Africa's CommunalLand Rights Act. Cape Town: UCT Press, and Athens: OhioUniversity Press (3-31).

[18] Definition and Indicators of Sustainable Development, Available at: http://www.sustainablemeasures.com/Training/Indicat ors/Def-Brl.html, accessed on 25 January, 2017.

[19] Dixon, K. (2006), Working with mixed commons/anticommons property: mobilising customary land in Papua New Guinea, Harvard Environmental Law Review (Vol. 31); Available at: www.law.havard.edu>vol31_1>dixonpdf, accessed on 15 October, 2015.

[20] Du Plessis \& Frantz (2013)African Customary Land Rights in a Private Ownership Paradigm
[21] Elkington, J. (1997), Cannibals with Forks - Triple bottom line of 21st century business, Stoney Creek, CT: New Society Publishers.

[22] FAO (2012), Voluntary guidelines on the responsible governance of tenure (VGGT), UN, Rome; Available at: http://www.fao.org/docrep/016/i2801e/i2801e.pdf, accessed on 12 February, 2017.

[23] Filer, C. (2012), The New Land Grab in Papua New Guinea, Resource Management in Asia-Pacific Program, Crawford School of Economics and Government, Australian National University; Available at: http://actnowpng.org/sites/default/files/The\%20new\% 20land\%20grab\%20in\%20Papua\%20New\%20Guinea \%20Colin\%20Filer.pdf., accessed on 6 April, 2017.

[24] Filer, C. (2007), Local Custom and the Art of Land Group Boundary Maintenance in Papua New Guinea, Australia National University; Available at: http://press.anu.edu.au/apem/customary/mobile_devic es/ch07s02.html,accessed on 4 October, 2015.

[25] Fingleton, J. S. (1998), Legal Recognition of Indigenous Groups, Rome; Available at:

[26] http://press.anu.edu.au/apem/customary/mobile devic es/ch07s02.html, accessed on 15 May, 2014.

[27] Goldman, L. (2005), PNG Gas Project Social Impact Assessment,' Brisbane: Exxon Mobil; Available at: http://press.anu.edu.au/apem/customary/pdf/ch06.pdf; accessed on 14 December, 2015.

[28] Grant, D., Ting, L. and Williamson, I. (1999), The Evolving Role of Land Administration in Support of Sustainable Development: A review of the United Nations: International Federation of Surveyors, Bathurst Declaration on Land Administration for Sustainable Development: Sustainable development is just rhetoric without appropriate land administration systems, Position Paper, Department of Geomatics, University of Melbourne, Australia.

[29] Green Peace Australia Pacific (2014), Available at: http://www.greenpeace.org/australia/en/what-we-do/, accessed on 12 December, 2015.

[30] Karigawa, L. (2015), Issues Affecting Incorporated Land Groups (ILGs) and their Sustainability in Papua New Guinea: A Case Study of Morobe Province, An MPhil Thesis in the Department of Surveying and Land Studies, Papua New Guinea University of Technology, Lae, Papua New Guinea.

[31] Kalinoe, L. K. (2001), Incorporated Land Groups in Papua New Guinea, MLJ 4; [2003-04] 29 Melanesian Law Journal 73; Available at: 
http://www.google.com.pg/search?q=ilg+ing\&biw=32

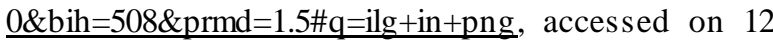
November, 2015).

[32] Kocmanova, A. and Simberova, I. (2014), Determination of Environmental, Social and Corporate Governance Indicators: Framework in the Measurement of Sustainable Performance, Journal of Business Economics and Management, Volume $\underline{15}$, Issue 5, pp. 1017-1033.

[33] Kwapena, F. (2014), Empowering Customary Landowners to give Value to their Land: NRI Commentry, Port Moresby; Available at: www.pngpeles.com>index.php > 272-empoweringcustomary-landowners-to-give-value-to-their-land; accessed on 15 May, 2015.

[34] Lakau, A. (1991), State Acquisition of Customary Land for Public Purposes in Papua New Guinea, Department of Surveying and Land Studies, Papua New Guinea University of Technology, Lae.

[35] Larcom, S. (2016), Natural Resource Contests and Precolonial Institutions in Papua New Guinea, Available at: http://onlinelibrary.wiley.com/doi/10.1111/joac.12169/ abstract, accessed on 7 April, 2017.

[36] Leavoy, P. (2016), Sustainability Reporting: The What and Why? Available at:

[37] http://www.environmentalleader.com/2014/09/15/sust ainability-reporting-the-what-and-why/, accessed on 22 January, 2017.

[38] Making Land Work - Volume One: Reconciling customary land and development in the Pacific; Available at:

[39] http://dfat.gov.au/aboutus/publications/Documents/MLW_VolumeOne_Book marked.pdf, accessed on 21 January, 2017.

[40] Minister of Land's Indictment of the Department of Lands (DLPP); Available at http://lands.gov.pg/Services/Governance/Complaints Desk.html, accessed on 23 January, 2017.

[41] North Dakota Oil Pipeline Battle, USA; Available at: https://www.nytimes.com/2016/11/02/us/north-dakotaoil-pipeline-battle-whos-fighting-and-why.html? $\mathrm{r}=0$, accessed on 12 February, 2017.

[42] Ogle. L. and Tararia, A. (2001), Incorporated Land Groups and the Registration of Customary Land: Recent Developments in PNG; Available at: http://milda.aidwatch.org.au/, accessed on 14 December, 2015.
[43] Oliver, N. and Fingleton, J. (2008), Settling customary land disputes in Papua New Guinea. In Making Land Work, Volume Two: Case Studies on Customary Land and Development in the Pacific; Aus AID: Canberra, Australia, pp. 223-240.

[44] O'Riordan, T. (1989), The challenge for environmentalism, in New Models in Geography, Peet, R. and Thrift, N. (Eds), Unwin Hyman: London; pp. 77-102.

[45] Petrosyan, A. F. (2010), A Model for Incorporated Measurement of Sustainable Development Comprising Remote Sensing Data and Using the Concept of Biodiversity, Journal of Sustainable Development, Vol. 3, No. 2, pp. 9-26.

[46] Power, A. P. (2001), Land Mobilisation in Papua New Guinea. Port Moresby, PNG (ed.) 2000, Land group incorporation: village guide and legal guide, Anutech/AusAID, Canberra; Available at: www.pngbuai.com>land-development, accessed on 19 December, 2014.

[47] Robinson, G., Available at: http://www.wri.org/blog/2015/02/qa-mark-robinsonrole-good-governance-sustainable-development, accessed on 10 February, 2017.

[48] Stratified Random Sample; Available at: http://study.com/academy/les son/stratified-ramdomsample-definition-quiez.html, accessed on 12 December, 2015.

[49] Sustainability; Available at: http://www.kennucorked.com>sustainabilitydefinition.html, accessed on 13 December, 2015.

[50] Ogle. L \& Tararia, A. (2007). Incorporated Land Groups and the Registration ofCustomary LandRecent Developments in PNG. http://scholar.google.com/scholar?um=1\&ie-UTF$\underline{8 \& \operatorname{lr} \& \text { cites }=10774025897395858495}, \quad 14^{\text {th }}$ August, 2015

[51] Tumare, J., Babarinde, J. A. and Tagicakibau, M. (2015), A Conceptual Framework for Multipurpose Land Information System (MPLIS) Application for Land Management in Papua New Guinea, Journal of Geomatics and Property Studies, Vol. 1, pp. 69-80.

[52] UNICEF (2012), At a glance: Papua New Guinea; Available at: https://www.unicef.org/infobycountry/papuang statisti cs.html, accessed on 10 April, 2017.

[53] Weber, M. (2005), What role for politics in the governance of complex innovation systems? New concepts, requirements and processes of an interactive 
technology policy for sustainability, in: U. Petschew, J. N. Rosenau \& E. U. von Weizsacker (Eds), Governance and Sustainability, New Challenges for States, Companies and Civil Society, pp. 100-118, Sheffield: Greenleaf.

[54] Weiner, J. F. (2000), Audit of Foi Incorporated Land Groups: Results and Analyses, Chevron Report to Minister of Petroleum and Energy, Australia, Available at:

[55] http://press.anu.edu.au/apem/customary/mobile devic es/ch07s02.html, accessed on 12 May, 2015.

[56] Weiner, J. F. and Glaskin, K. (Eds.) (2007), Customary Land Tenure and Registration in Australia and Papua New Guinea: Anthropological Perspectives, Asia-Pacific Environment Monograph 3, pp. 1-297.

[57] World Resources Institute (2015), Q\&A with Mark Robinson: The Role of Good Governance in Sustainable Development by Madaleine Weber February 18; Available at: http://www.wri.org/blog/2015/02/qa-mark-robinsonrole-good-governance-sustainable-development, accessed on 25 January, 2017.

[58] Yala, C. (2010), The genesis of the Papua New Guinea land reform programmes, Port Moresby: The National Research Institute.

[59] Young, M. (1990), Fieldwork Report: Logging or Conservation on Woodlark (Muyuw) Island. Department of Anthropology, Research School of Pacific Studies, Australian National University; Available at: www.ulg.ac.be>PARROTS $>$ YOUNG, accessed on 14 December, 2015. 